\title{
EFEK INFUSA DAGING BUAH MAHKOTA DEWA (Phaleria macrocarpa (Sceff.) Boerl.) TERHADAP PENURUNAN KADAR ASAM URAT DARAH MENCIT PUTIH JANTAN YANG DIINDUKSI DENGAN POTASSIUM OXONATE
}

\section{THE REDUCING EFFECT OF URIC ACID BLOOD LEVEL OF INFUSA OF Phaleria PULP IN MALE MICE INDUCED BY POTASSIUM OXONATE}

\author{
EM Sutrisna*, Arifah Sri Wahyuni, Lusi Agus Setiani \\ Fakultas Farmasi, Universitas Muhammadiyah Surakarta \\ em_sutrisna@yahoo.com
}

\begin{abstract}
ABSTRAK
Mahkota dewa (Phaleria macrocarpa (Sceff.) Boerl.) merupakan tanaman yang secara empiris telah dimanfaatkan untuk mengobati penyakit salah asam urat. Perasan daging buah mahkota dewa dosis 13,16 g/kgBB tealah terbukti dapat menurunkan kadar asam urat darah pada ayam jantan jenis Lohman Brown. Penelitian ini bertujuan untuk mengetahui efek infusa daging buah mahkota dewa dalam menurunkan kadar asam urat mencit putih jantan yang diinduksi potassium oxonate. Penelitian ini merupakan penelitian eksperimental dengan rancangan penelitian acak lengkap pola searah. Mencit jantan sebanyak 25 ekor diberi jus hati ayam konsentrasi 10\% sebanyak 3 kali sehari selama 2 hari. Kemudian dibagi menjadi 5 kelompok. Kelompok I (kontrol negatif) diberi aqua p.o 0,5 ml/20 gBB. Kelompok II (kontrol positif) diberi allopurinol p.o $10 \mathrm{mg} / \mathrm{kgBB}$. Kelompok III, IV dan $\mathrm{V}$ diberi infusa daging buah mahkota dewa dengan dosis berturut-turut 1,25; 2,5 dan $5 \mathrm{~g} / \mathrm{kgBB}$. Hewan uji diinduksi dengan potassium oxonate $250 \mathrm{mg} / \mathrm{kgBB}$ secara intraperitoneal 1 jam setelah pemberian sediaan uji untuk menaikkan kadar asam urat. Serum darah diambil dari vena opthalmicus pada jam ke 2 setelah induksi. Kadar asam urat ditetapkan dengan spektrofotometer visibel pada panjang gelombang $546 \mathrm{~nm}$. Hasil menunjukkan infusa daging buah mahkota dewa dosis 1,25; 2,5 dan $5 \mathrm{~g} / \mathrm{kgBB}$ mampu menurunkan kadar asam urat darah dalam serum mencit putih jantan yang diinduksi potassium oxonate dosis $250 \mathrm{mg} / \mathrm{kgBB}$ dan setara dengan kontrol positif (allopurinol $10 \mathrm{mg} / \mathrm{kgBB}$ ).
\end{abstract}

Kata kunci : Phaleria macrocarpa (Sceff.) Boerl., asam urat

\section{ABSTRACT}

Phaleria macrocarpa is a plant that are empirically used to treat various diseases one of which uric acid. Previous studies have shown that the juice of pulp Phaleria middle dose $13.16 \mathrm{~g} /$ $\mathrm{kgBW}$ colud decrease blood uric acid levels in male type Lohman Brown chicken. This study aimed to determine the effect of pulp infusa Phaleria in lowering uric acid levels of male white mice induced by potassium oxonate. This study is a randomized experimental design with complete unidirectional design. Male mice of 25 mice were treated the chicken liver juice concentrate 10\% three times daily for 2 days. Then divided into five groups. Group I (negative control) were treated po $0.5 \mathrm{cc} / 20 \mathrm{~g}$ aqua. Group II (positive control) were given allopurinol po $10 \mathrm{mg} / \mathrm{kgBW}$. Group III, IV and $V$ were treated pulpa infusa Phaleria with consecutive doses of 1.25; 2.5 and $5 \mathrm{~g} / \mathrm{kgBW}$. Mice were induced with potassium oxonate $250 \mathrm{mg} / \mathrm{kgBW}$ intraperitoneally 1 hour after administration of test preparations to raise uric acid levels. Blood serum collected from opthalmicus vein two hour after induction. Uric acid levels determined by visible spectrophotometer at a wavelength of 546 $\mathrm{nm}$. Results showed infusa pulp Phaleria doses $1.25,2.5$ and $5 \mathrm{~g} / \mathrm{kg}$ body weight could decrease blood uric acid levels in serum of male albino mice induced by potassium oxonate dose $250 \mathrm{mg} / \mathrm{kg}$ and equivalent to a positive control (allopurinol $10 \mathrm{mg} / \mathrm{kgBW}$ ).

Keyword : Phaleria macrocarpa (Sceff.) Boerl.), uric acid

\section{PENDAHULUAN}

Asam urat adalah produk akhir dari metabolisme purin, yang dapat mengendap dalam jaringan dan bisa menyebabkan peradangan yang dikenal dengan nama gout atau encok. Gout merupakan salah satu penyakit metabolik yang terjadi akibat tingginya kadar asam urat dalam darah. Kadar asam urat dalam darah sangat erat kaitannya dengan pola hidup yang dijalani, pola konsumsi makanan yang salah, serta penyalahgunaan alkohol yang terjadi di masyarakat secara meluas (Simon et al., 2001). 
Dari waktu ke waktu jumlah penderita asam urat cenderung meningkat. Berdasarkan data dari Rumah Sakit Umum Nasional Dr. Cipto Mangunkusumo menunjukkan terjadi kenaikan penderita sekitar 9 orang dari tahun 1993 sampai 1994 dan sekitar 19 orang dari 1994 sampai 1995 (Utami, 2003). Pada tahun 2007, menurut data pasien yang berobat di klinik RS Cipto Mangun Kusumo (RSCM) Jakarta, penderita asam urat sekitar $7 \%$ dari keseluruhan pasien yang menderita penyakit rematik (Anonim, 2009).

Flavonoid dalam tumbuhan terdapat dalam bentuk aglikon ataupun bentuk glikosida. Senyawa ini mempunyai tingkat kepolaran dari non polar sampai dengan polar, dan dapat dimungkinkan tersari dalam penyari polar sampai dengan non polar. Dengan demikian, diharapkan flavonoid dapat tersari dalam pelarut air yang bersifat polar pada sediaan infusa.

Berdasarkan penggunaan empiris di masyarakat dan hasil penelitian yang telah dilakukan, tanaman mahkota dewa berpotensi untuk dikembangkan sebagai jamu, obat tradisional obat herbal terstandar bahkan berpotensi sebagai fitofarmaka. Sehingga perlu dilakukan penelitian untuk membuktikan keefektifan tanaman mahkota dewa sebagai penurun kadar asam urat. Hasil penelitian ini diharapkan dapat dijadikan bukti ilmiah tentang efek infusa daging buah mahkota dewa dalam menurunkan kadar asam urat dan memberikan sumbangan pada masyarakat tentang obat tradisional yang saat ini masih berdasarkan pada data empiris.

\section{METODE PENELITIAN \\ Rancangan Penelitian}

Penelitian ini merupakan penelitian eksperimental semu dengan rancangan acak lengkap pola searah.

\section{Variabel penelitian}

1) Variabel bebas : perlakuan yakni kontrol positif, kontrol negatif, kontrol normal, kontrol hiperurisemia dan infusa dari daging buah mahkota dewa (Phaleria marcocarpa (Sceff.) Boerl.) dengan dosis tertentu.

2) Variabel tergantung : kadar asam urat dalam serum.

3) Variabel terkendali : a) makanan dan minuman, semua hewan uji diberi makanan buatan (pellet), minum aquadest ad libitum, pemberian jus hati ayam konsentrasi $10 \%$ tiga kali sehari selama 2 hari. b) kadar asam urat hewan uji sebelum perlakuan harus normal.

\section{Alat dan Bahan \\ Alat}

Timbangan analitik (Presica A-SCS), spuit injeksi (Terumo), spuit injeksi untuk insulin, spuit oral 15 gauge (Terumo), flakon, timbangan mencit kapasitas 2610 gram (Lark, Cina), timbangan analitik (Presica ASCS), pipa kapiler (Assistent), sentrifuge (mini spin), vortex, mikropipet ukuran 5-40 $\mu$; 200-1000 $\mu$ l, blue tip, Spektrofotometer UV-VIS (StarDust FC* 15), kuvet disposibel dan alatalat gelas (Pyrex).

\section{Bahan}

Simplisia daging buah mahkota dewa, mencit putih jantan dengan berat badan 20-30 gram dan berumur 2-3 bulan, aquadest, potassium oxonate sebagai inhibitor xanthine oxydase, allopurinol (kontrol positif), CMC Na dan pereaksi dalam penetapan kadar asam urat reagen Uric Acid FS* TBHBA (DiaSys).

\section{Jalan Penelitian \\ Determinasi Tanaman}

Determinasi tanaman ini adalah untuk menetapkan kebenaran sampel tanaman mahkota dewa yang berkaitan dengan ciri-ciri makroskopis serta mencocokkan ciri-ciri morfologis yang ada dengan pustaka. Determinasi dilakukan di Balai Penelitian Tanaman Obat (B2P2T2OT) Tawangmangu, Karanganyar, Jawa Tengah.

\section{Pembuatan Infusa Daging Buah Mahkota Dewa}

Daging buah mahkota dewa yang telah dicuci dimasukkan dalam panci infus ditambah aquadest $100 \mathrm{ml}$ dan air ekstra sebanyak dua kali bobot daging buah mahkota dewa. Panci dipanaskan selama 15 menit dihitung mulai suhunya mencapai $90^{\circ} \mathrm{C}$ sambil sekali-kali diaduk. Infusa diserkai selagi panas melalui kain flannel. Untuk mencukupi kekurangan air, dapat menambahkan air melalui ampasnya.

\section{Penentuan Dosis}

1. Dosis allopurinol yang digunakan adalah $10 \mathrm{mg} / \mathrm{kgBB}$ atau $0,2 \mathrm{mg} / 20 \mathrm{gBB}$ (Zhao et al., 2005).

2. Dosis infusa daging buah mahkota dewa yang diberikan pada hewan uji dalam penelitian adalah 1,25; 2,5 dan $5 \mathrm{~g} / \mathrm{kgBB}$ (konsentrasi 5\%, 10\% dan 20\%).

\section{Pembuatan Hiperurisemia}

Kadar asam urat tinggi (hiperurisemia) dibuat dengan cara menginduksi secara intraperitoneal potassium oxonate 250 $\mathrm{mg} / \mathrm{kgBB}$ pada mencit 1 jam setelah pemberian sediaan uji (Mo et al., 2007), dan sebelumnya 
hewan uji diberi sediaan jus hati ayam dengan konsentrasi $10 \%$ sebanyak tiga kali sehari selama dua hari.

\section{Uji Pendahuluan}

Uji pendahuluan pembuatan model hiperurisemia dilakukan pada 9 ekor mencit putih jantan yang dibagi menjadi 3 kelompok masing-masing 3 ekor,setiap kelompok diberi perlakuan peroral dengan volume $0,5 \mathrm{ml} / 20$ gBB dengan :

a. Kelompok A : diberi CMC Na 0,5\%, satu jam kemudian diberi CMC $\mathrm{Na}$ $0,5 \%$ i.p $0,5 \mathrm{ml} / 20 \mathrm{gBB}$.

b. Kelompok B : diberi aquadest, satu jam kemudian diberi aquadest i.p 0,5 ml/20 gBB.

c. Kelompok $\mathrm{C}$ : diberi aquadest, satu jam kemudian diinduksi potassium oxonate i.p $250 \quad \mathrm{mg} / \mathrm{kgBB} \quad$ (kelompok hiperurisemia).

\section{Uji Perlakuan}

Perlakuan terhadap hewan uji dilakukan pada jam 07.00-12.00 WIB, menggunakan 25 ekor mencit yang telah ditimbang lalu dibagi menjadi 5 kelompok masing-masing 5 ekor kemudian darah diambil dari vena opthalmicus 0,5 ml, 1 jam sebelum diberikan perlakuan, yaitu:

a. Kontrol negatif : diberi aquades p.o 0,5 $\mathrm{ml} / 20 \mathrm{gBB}$.

b. Kontrol positif : diberi allopurinol p.o 10 $\mathrm{mg} / \mathrm{kgBB}$.

c. Infusa 1 : diberi infusa mahkota dewa konsentrasi $5 \%$ p.o 1,25 g/KgBB.

d. Infusa 2 : diberi infusa mahkota dewa konsentrasi $10 \%$ p.o $2,5 \mathrm{~g} / \mathrm{KgBB}$.

e. Infusa 3 : diberi infusa mahkota dewa $20 \%$ p.o $5 \mathrm{~g} / \mathrm{KgBB}$.

Satu jam kemudian kelompok I-V diberikan induksi potassium oxonate $250 \mathrm{mg} / \mathrm{kgBB}$ intraperitoneal.

\section{Pengambilan Darah}

Dua (2) jam setelah induksi hiperurisemia dengan injeksi potassium oxonate dosis 250 $\mathrm{mg} / \mathrm{kgBB}$, darah diambil lewat vena opthalmicus. Darah ditampung kurang lebih sebanyak 0,5 $\mathrm{ml}$ dalam mikrotube. Darah yang ditampung dijaga agar tidak terjadi hemolisis. Darah dibuat serum dengan cara disentrifugasi dengan kecepatan 5000 rpm selama 5 menit.

\section{Penetapan Kadar Asam Urat}

Kadar asam urat ditetapkan berdasarkan reaksi enzymatic menggunakan reagen uric acid $\mathrm{FS}^{*}$ TBHBA. Larutan sampel dibuat dengan cara mengambil $20 \mu \mathrm{l}$ serum ditambah
$1000 \mu \mathrm{l}$ monoreagen (4 bagian Reagen 1 ditambah 1 bagian Reagen 2). Serum yang telah dicampur homogen dengan pereaksi Uric Acid FS* TBHBA diinkubasi selama 10 menit pada suhu $37^{\circ} \mathrm{C}$. Selanjutnya larutan sampel, standart dan blangko (aquadest) dibaca kadarnya pada panjang gelombang $546 \mathrm{~nm}$. dengan menggunakan spektrofotometer-Vis.

\section{Analisis Data}

Data yang diperoleh dari penelitian yang berupa kadar asam urat darah diuji statistik dengan analisis varian satu jalan dilanjutkan dengan uji Bonferroni dengan taraf kepercayaan 95\%. Dari data kadar asam urat darah tersebut dihitung prosentase penurunan dengan rumus sebagai berikut:

$$
\% \text { penurunan }=\frac{\text { rata }- \text { rata kontrol hiperurise mia }- \text { perlakuan }}{\text { rata }- \text { rata kontrol hiperurise ma }- \text { kontrol normal }} \times 100 \%
$$

\section{HASIL DAN PEMBAHASAN \\ Determinasi Tanaman}

Determinasi tanaman bertujuan untuk memastikan bahwa tanaman yang diteliti sesuai dengan yang dimaksud, sehingga tidak tejadi kesalahan dalam penggunaan tanaman. Determinasi tanaman dilakukan dengan cara mencocokkan ciri-ciri morfologi tanaman dengan pustaka, dilakukan di Balai Penelitian Tanaman Obat (B2P2T2OT) Tawangmangu, Karanganyar, Jawa Tengah dengan menggunakan pustaka Flora of Java (Backer, 1965). Hasil determinasi adalah sebagai berikut: 1b, 2b, 3b, 4b, 12b, 13b, 14b, 17b, 18b, 19b, 20b, 21b, 22b, 23b, 24b, 25b, 26b, 27b, $799 b, 800 b, 801 b, 802 a, 803 b, 804 b, 805 c$, $806 \mathrm{~b}, 807 \mathrm{a}, 808 \mathrm{c}, 809 \mathrm{~b}, 810 \mathrm{~b}, 811 \mathrm{a}, 812 \mathrm{~b}$, $815 b, 816 b, 818 b, 820 b, 821 b, 822 b, 824 b$, $825 \mathrm{~b}, 826 \mathrm{~b}, 829 \mathrm{~b}, 830 \mathrm{~b}, 831 \mathrm{~b}, 832 \mathrm{~b}, 833 \mathrm{~b}$, $834 \mathrm{a}, 835 \mathrm{a}, 836 \mathrm{a}, 837 \mathrm{c}, 851 \mathrm{a}, 852 \mathrm{~b}, 853 \mathrm{~b}$, $854 \mathrm{a}, 855 \mathrm{c}, 856 \mathrm{~b}, 857 \mathrm{a}, 858 \mathrm{~b}, 860 \mathrm{~b}, 872 \mathrm{~b}$, $874 b, 875 b, 876 b, 877 d, 933 b, 934 a, 935 b$, 936b, 937a, 938c, 939a, 940a, 941b, 942b 64. Thymelaeaceae

1a_. Phaleria

1a_2b_Phaleria macrocarpa (Scheff.) Boerl.

Dari hasil determinasi dapat dipastikan bahwa tanaman yang digunakan dalam penelitian adalah tanaman mahkota dewa (Phaleria macrocarpa (Sceff) Boerl.

\section{Hasil Uji Pendahuluan}

Uji pendahuluan dilakukan untuk mendapatkan model hiperurisemia pada mencit putih jantan galur swiss dengan diinduksi potassium oxonate secara intraperitoneal pada pukul 09.00-10.00 (Haidari et al., 2008). Uji dilakukan dengan membandingkan kadar asam 
urat setelah diinduksi potassium oxonate 250 $\mathrm{mg} / \mathrm{kgBB}$ secara intraperitoneal (tabel 1).

Tabel 1- Data Kadar Asam Setelah Pemberian CMC Na, Aquadest dan Potassium oxonate $(\mathrm{n}=3)$

\begin{tabular}{cccc} 
Perlakuan & $\begin{array}{c}\text { Hewan } \\
\text { Uji }\end{array}$ & $\begin{array}{c}\text { Kadar } \\
\text { Asam } \\
\text { urat } \\
(\mathrm{mg} / \mathrm{dL})\end{array}$ & $\begin{array}{c}\overline{\mathrm{X}} \pm \mathrm{SD} \\
(\mathrm{mg} / \mathrm{dL})\end{array}$ \\
\hline CMC Na 0,5\% i.p & 1 & 2,4 & \\
(normal) & 2 & 2,5 & $2,57 \pm$ \\
& 3 & 2,8 & 0,21 \\
Aquadest & 1 & 1,8 & \\
(normal) & 2 & 2,6 & $1,80 \pm$ \\
Potassium oxonate i.p & 3 & 1,0 & 0,80 \\
250 mg/kgBB & 1 & 3,4 & \\
(Hiperurisemia) & 2 & 3,6 & $4,13 \pm$ \\
& 3 & 5,4 & 1,10 \\
\hline
\end{tabular}

Pemberian potassium oxonate dosis 250 $\mathrm{mg} / \mathrm{kgBB}$ dengan waktu pengambilan darah yang optimal terjadi pada jam ke-2 memperlihatkan bahwa induksi mampu meningkatkan kadar asam urat sampai dengan $4,13 \pm 1,10 \quad(p<0,05)$ dibandingkan terhadap kontrol normal (tabel 1). Mo (2007) menyatakan hiperurisemia terjadi bila kadar asam uratnya mencapai lebih dari $3,3 \mathrm{mg} / \mathrm{dl}$, sehingga pembuatan model hiperurisemia dapat dikatakan berhasil.

\section{Hasil Uji Infusa Daging Buah Mahkota Dewa}

Sediaan uji yang digunakan untuk menurunkan asam urat dalam penelitian ini adalah infusa daging buah mahkota dewa yang disari dengan metode infundasi. Metode ini merupakan cara yang mirip dengan penggunaan bahan nabati sebagai obat tradisional yaitu dengan merebus bahan dan mengambil konsentratnya untuk diminum sehingga kesetaraan perlakuan penggunaan secara tradisional dan perlakuan dalam penelitian identik. Daging buah mahkota dewa yang digunakan dalam penelitian ini berupa simplisia. Senyawa kimia yang terkandung dalam buah mahkota dewa antara lain golongan alkaloid, tannin, flavonoid, fenol, saponin, lignin, minyak atsiri dan sterol (Hendra et al. 2011).

Penetapan kadar asam urat ditetapkan dengan metode enzimatik, dengan menggunakan reagen Uric acid $F S^{*}$ TBHBA (2,4,6-tribromo-3hydroxybenzoic acid dengan menggunakan alat spektrofotometer StarDust FC 15. Mekanisme yang terjadi adalah asam urat dioksidasi oleh enzim urikase dengan bantuan $\mathrm{H}_{2} \mathrm{O}$ dan $\mathrm{O}_{2}$ menjadi allantoin, karbondioksida dan hidrogen peroksida. Hidrogen peroksida yang terbentuk akan bereaksi dengan 4-amino antipirin dan TBHBA (2,4,6-tribromo-3hydroxybenzoic acid) menjadi kuinonimin yang berwarna merah muda dimana reaksi tersebut dikatalisis oleh enzim peroksidase (gambar 1). Besarnya intensitas warna yang dihasilkan oleh kuinonimin tersebut ekuivalen dengan kadar asam urat dalam darah.

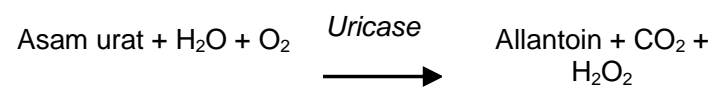

TBHBA (2,4,6-tribromo-3hidroxybenzoic acid) + 4Aminoantipirin $+\mathrm{H}_{2} \mathrm{O}_{2}$

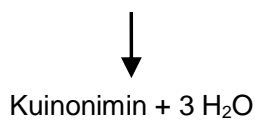

Gambar 1- Mekanisme Reaksi Pembentukan Senyawa Kuinonimin

Perlakuan dengan infusa daging buah mahkota dewa menunjukkan kemampuan menurunkan kadar asam urat (tabel 2). Kadar asam urat setelah pemberian infusa dosis 1,25; 2,5 dan $5 \mathrm{~g} / \mathrm{kgBB}$ terlihat mampu menurunkan kadar asam urat sampai dengan $0,96 \pm 0,39$.

Tabel 2- Data Baseline dan Kadar Asam Urat (mg/dl) Serum Mencit Jantan Setelah Perlakuan $(n=5)$

\begin{tabular}{|c|c|c|c|c|}
\hline Kelompok & $\begin{array}{l}\text { No. } \\
\text { HU }\end{array}$ & $\begin{array}{c}\text { Baseline } \\
\text { kadar } \\
\text { asam urat } \\
(\mathrm{mg} / \mathrm{dl}) \\
\end{array}$ & $\begin{array}{c}\text { Kadar } \\
\text { setelah } \\
\text { perlakuan } \\
(\mathrm{mg} / \mathrm{dl}) \\
\end{array}$ & $\begin{array}{c}\text { Xkadar } \\
\text { setelah } \\
\text { perlakuan } \pm \\
\text { SD }(\mathrm{mg} / \mathrm{dl})\end{array}$ \\
\hline \multirow{5}{*}{$\begin{array}{l}\text { Kontrol Negatif } \\
\text { (Hiperurisemia) }\end{array}$} & 1 & 1,2 & 3,6 & \multirow{5}{*}{$3,66 \pm 0,13$} \\
\hline & 2 & 2,1 & 3,5 & \\
\hline & 3 & 1,5 & 3,8 & \\
\hline & 4 & 1,4 & 3,8 & \\
\hline & 5 & 1,6 & 3,6 & \\
\hline \multirow{5}{*}{$\begin{array}{c}\text { Kontrol Positif } \\
\text { (Allpurinol } 10 \\
\text { mg/kgBB) }\end{array}$} & 1 & 2,6 & 1,3 & \multirow{5}{*}{$0,94 \pm 0,35$} \\
\hline & 2 & 1,3 & 0,5 & \\
\hline & 3 & 3,1 & 0,8 & \\
\hline & 4 & 2,5 & 1,3 & \\
\hline & 5 & 1,8 & 0,8 & \\
\hline \multirow{5}{*}{$\begin{array}{c}\text { Infusa daging } \\
\text { buah mahkota } \\
\text { dewa } \\
1,25 \mathrm{~g} / \mathrm{kgBB}\end{array}$} & 1 & 1,8 & 1,4 & \multirow{5}{*}{$1,46 \pm 0,50$} \\
\hline & 2 & 2,4 & 1,9 & \\
\hline & 3 & 1,3 & 0,8 & \\
\hline & 4 & 2,6 & 2,0 & \\
\hline & 5 & 2,2 & 1,2 & \\
\hline \multirow{5}{*}{$\begin{array}{c}\text { Infusa daging } \\
\text { buah mahkota } \\
\text { dewa } \\
2,5 \mathrm{~g} / \mathrm{kgBB}\end{array}$} & 1 & 1,0 & 0,6 & \multirow{5}{*}{$0,96 \pm 0,39$} \\
\hline & 2 & 1,2 & 0,6 & \\
\hline & 3 & 1,5 & 1,2 & \\
\hline & 4 & 1,9 & 1,5 & \\
\hline & 5 & 1,1 & 0,9 & \\
\hline \multirow{5}{*}{$\begin{array}{c}\text { Infusa daging } \\
\text { buah mahkota } \\
\text { dewa } 5 \\
\text { g/kgBB }\end{array}$} & 1 & 2,1 & 0,9 & \multirow{5}{*}{$1,02 \pm 0,40$} \\
\hline & 2 & 2,8 & 1,6 & \\
\hline & 3 & 2,5 & 1,0 & \\
\hline & 4 & 1,5 & 0,5 & \\
\hline & 5 & 1,9 & 1,1 & \\
\hline
\end{tabular}

Penurunan ini menunjukkan perbedaan dengan kontrol negatif (hiperurisemia) $(p<0,05)$, sehingga dapat dikatakan infusa daging buah mahkota dewa dosis 1,$25 ; 2,5$ dan $5 \mathrm{~g} / \mathrm{kgBB}$ memiliki efek penurunan kadar asam urat dalam darah pada mencit jantan yang dibuat 
hiperurisemia. Efek tersebut sebanding dengan allopurinol dosis $10 \mathrm{mg} / \mathrm{kgBB}(\mathrm{p}>0,05)$.

Tabel 3- Persentase Penurunan Kadar Asam Urat Serum Mencit Putih Jantan Terhadap Kontrol Hiperurisemia

\begin{tabular}{cccc}
\hline Kelompok & No.HU & $\begin{array}{c}\text { Persentase } \\
\text { Penurunan }(\%)\end{array}$ & $\bar{X} \pm \mathrm{SD}(\%)$ \\
\hline & 1 & 64,48 & \\
Allopurinol & 2 & 86,34 & \\
$10 \mathrm{mg} / \mathrm{kgBB}$ & 3 & 78,14 & \\
& 4 & 64,48 & $74,32 \pm 9,58$ \\
& 5 & 78,14 & \\
Infusa daging & 1 & 61,75 & \\
buah & 2 & 48,09 & \\
mahkota & 3 & 78,14 & \\
dewa & 4 & 45,36 & $60,11 \pm 13,60$ \\
1,25g/kgBB & 5 & 67,21 & \\
& & & \\
Infusa daging & 1 & 83,61 & \\
buah & 2 & 83,61 & \\
mahkota & 3 & 67,21 & $73,77 \pm 10,69$ \\
dewa 2,5 & 4 & 59,02 & \\
g/kgBB & 5 & 75,41 & \\
Infusa daging & 1 & 75,41 & \\
buah & 2 & 56,28 & \\
mahkota & 3 & 72,68 & \\
dewa 5 & 4 & 86,34 & $72,13 \pm 10,83$ \\
g/kgBB & 5 & 69,95 & \\
\hline
\end{tabular}

Kemampuan penurunan asam urat sediaan infusa daging buah mahkota dewa dosis 1,25, 2,5 dan $5 \mathrm{~g} / \mathrm{kgBB}$ dibandingkan dengan sediaan ekstrak menunjukkan persentase penurunan berturut-turut $60,11 \%$, $73,77 \%$ dan $72,13 \%$. Jika dibandingkan dengan ekstrak etanol daging buah mahkota dewa, keefektifan infusa mahkota dewa dalam menurunkan kadar asam urat sebanding. ekstrak etanol daging buah mahkota dewa dosis $5 \mathrm{~g} / \mathrm{kgBB}$ dapat menurunkan $72,68 \%$ dari kondisi hiperurisemia (Azmi, 2010). Hal ini dikarenakan senyawa aktif yang diduga memiliki kemampuan menghambat xanthine oxydase seperti flavonoid (Cos et al., 1998) yang terikat dalam bentuk glukosa bersifat polar sehingga lebih mudah tersari dalam pelarut polar.

Menurut Markham (1988) flavonoid dalam tanaman mahkota dewa dapat berbentuk aglikon maupun glukosa. Kepolaran senyawa flavonoid adalah dari non polar sampai dengan polar, sehingga dapat disari dalam penyari yang polar sampai dengan non polar. Keefektifan mahkota dewa pada pelarut non polar dinyatakan pada hasil penelitian Habsari (2010) bahwa ektrak heksan daging buah mahkota dewa dosis $2,5 \mathrm{~g} / \mathrm{kgBB}$ dapat menurunkan kadar asam urat sebesar $80,33 \%$ dari kondisi hiperurisemia.

Pada kelompok III dan IV (tabel 3) menunjukkan hasil yang tidak berbeda bermakna sehingga tidak perlu dilakukan penelitian lebih lanjut untuk mengetahui berapa kadar optimal yang mampu menurunkan kadar asam urat serum mencit putih jantan karena tingkat penurunan dari infusa daging buah mahkota dewa yang optimal telah terjadi pada dosis $2,5 \mathrm{~g} / \mathrm{kgBB}$. Sehingga perlu dilakukan pemberian pada dosis di bawah $1,25 \mathrm{~g} / \mathrm{kgBB}$ untuk mengetahui keefektifannya pada dosis yang lebih rendah.

Efek penurunan kadar asam urat infusa daging buah mahkota dewa diduga disebabkan oleh penghambatan xanthine oxydase. Jenis flavonoid yang berperan dalam mekanisme penghambatan enzim xanthine oxydase adalah flavon dan flavonol (Cos et al., 1998). Keefektifan tersebut diduga karena flavonoid aglikon yang dapat terlarut pada pelarut non polar, namun perlu dilakukan penelitian lebih lanjut untuk meneliti senyawa aktif selain flavonoid dalam infusa daging buah mahkota dewa yang bertanggung jawab menurunkan kadar asam urat dalam darah tersebut.

\section{KESIMPULAN DAN SARAN \\ KESIMPULAN}

1. Berdasarkan data hasil penelitian, infusa daging buah mahkota dewa (Phaleria macrocarpa (Sceff.) Boerl.) dengan dosis $1,25, \quad 2,5$ dan $5 \mathrm{~g} / \mathrm{kgBB}$ mampu menurunkan kadar asam urat dalam serum mencit putih jantan yang diinduksi dengan potassium oxonate dosis $250 \mathrm{mg} / \mathrm{kgBB}$, penurunan tersebut setara dengan allopurinol $10 \mathrm{mg} / \mathrm{kgBB}(\mathrm{p}>0,05)$.

2. Sediaan infusa daging buah mahkota dewa terbukti dapat menurunkan kadar asam urat serum mencit putih jantan secara optimal pada dosis $2,5 \mathrm{~g} / \mathrm{kgBB}$ yaitu menurunkan kadar asam urat sebesar $73,77 \% \pm 10,69$ terhadap kontrol hiperurisemia.

\section{SARAN}

1. Perlu dilakukan uji ketoksikan akut dan subakut untuk mengetahui tingkat keamanan penggunaan infusa daging buah mahkota dewa (Phaleria macrocarpa (Sceff.) Boerl.).

2. Perlu dilakukan penelitian lebih lanjut dengan mengukur aktivitas dari enzim xanthine oxydase untuk mengetahui mekanisme dari penurunan asam urat dalam darah sehingga dapat digunakan untuk terapi pengobatan asam urat.

\section{UCAPAN TERIMAKASIH}

Ucapan terimakasih kepada Rektor UMS, Dekan Farmasi UMS dan semua pihak yang membantu terselesainya penelitian ini. 


\section{DAFTAR PUSTAKA}

Anonim ${ }^{b}, 2009$, Data Pasien Asam Urat di RSCM (on line), (http://www.depkes.go.id) diakses 13 Agustus 2009.

Azmi, U., 2010, Efek Ekstrak Etanol Daging Buah Mahkota Dewa (Phaleria macrocrpa (Scheff.) Boerl) terhadap Penurunan Kadar Asam Urat Mencit Putih Jantan yang Diinduksi Potassium Oxonate, Skripsi, Fakultas Farmasi Universitas Muhammadiyah Surakarta, Surakarta.

Backer and Van den Brink, 1968, Flora of Indonesia (Spermatophyta Only), Volume 2, World of Bronirgen, Netherland

Cos, P., Ying, L., Calomme, M., Hu, J.P., Cimanga, K., Poel V.B., Pieters, L., Vlietinck, A.J and Berghe, D.V, 1998, Structure-Activity Releationship and Clacification of Flavonoids as Inhibitors of Xanthine Oxidase and Superoxide Scavengers, Journal of Natural Products, 71-76, Vol. 61

Habsari, N. R. E., 2010, Efek Ekstrak Heksan Daging Buah Mahkota Dewa (Phaleria macrocrpa (Scheff.) Boerl) terhadap Penurunan Kadar Asam Urat Mencit Putih Jantan yang Diinduksi Potassium Oxonate, Skripsi, Fakultas Farmasi Universitas Muhammadiyah Surakarta, Surakarta.

Haidari, F., Rashidi, M.R., Keshavarz, S., Mahboob, S.A., Eshraghian, M.R and Shahi, M.M., 2008, Effect of Onion on Serum Uric Acid Levels and Hepatic Xanthine Dehydrogenase/Xanthine Oxidase Activities in Hyperuricemic Rats, Journal of Biological Sciences, Tehran University of Medical Sciences, Iran.

Hendra, R. et al., 2011. Antioxidant, anti-inflammatory and cytotoxicity of Phaleria macrocarpa (Boerl.) Scheff Fruit. BMC complementary and alternative medicine, 11(1), p.110.

Markham, K.R., 1988, Cara Identifikasi Flavonoid, diterjemahkan oleh Padmawinata K., Penerbit ITB, Bandung.

Mo, S., Zhou, F., Lv, Y., Hu, Q., Zhang, D., and Kong, L., 2007, Hypouricemic Action of Selected Flavonoids in Mice : Structure-Activity Relationship, Nanjing University, China.

Simon, H., Etikun, M.J., Godine., Hellen, D., Kutter, I., Shellito, P.C., and Stern,T.A., 2001, Gout Information Service Inc, New York (http: //www. Nelconrected.com).

Utami, P., 2003, Tanaman Obat untuk Mengatasi Rematik dan Asam Urat, 28-30, Agromedia Pustaka,Jakarta

Zhao, X., Zhu, J.X., Mo, S.F., Pan, Y., Kong, L.D., 2005, Effect of Cassia Oil on Serum and Hepatic Uric Acid Levels in Oxonate Inducer Mice and Xanthine Oxidase Activities in Mouse Liver, Journal of Ethopharmacology. 